\title{
A Combined Strategy of Additive Manufacturing to Support Multidisciplinary Education in Arts, Biology, and Engineering
}

\author{
Henry A. Colorado ${ }^{1}$ (i) $\cdot$ David E. Mendoza ${ }^{1} \cdot$ Fernando L. Valencia ${ }^{2}$
}

Accepted: 6 October 2020 / Published online: 27 October 2020

(c) Springer Nature B.V. 2020

\begin{abstract}
This research presents results for the design and creation of supporting teaching materials using additive manufacturing. The materials are inspired by selected artwork of four animal species, which belong to a collection from the museum of the University of Antioquia. The topic selected was fauna in Colombia, and the animals in question were chosen based on important roles they have in areas like health, the environment, and food. These animals will complement science education given to several age groups visiting the museum. In addition to the 3D-manufactured objects, a study was conducted using several age groups that are very relevant to the museum: children, teenagers, and first year undergraduate students. A video showing technical information cards about the manufacturing process was also developed. This project was multidisciplinary, involving collaboration between the engineering school, the museum, and a local high school. The results showed that young visitors want complete information on the animals and to have interaction with the animal models, which is not always possible. This project serves as a local strategy not only for taking arts and knowledge out of the museum but also for planning first year courses in the university and thus reducing problems like school dropout, low motivation, and poor performance in national exams.
\end{abstract}

Keywords Teaching $\cdot$ Active learning $\cdot$ Additive manufacturing $\cdot$ Museum $\cdot$ Arts $\cdot$ Preservation $\cdot$ Didactics

\section{Introduction}

Nowadays, teaching and learning demand new methods and strategies to keep students motivated in the classroom. Correspondingly, there has been significant development of teaching methods and strategies for science and engineering which can facilitate the necessary changes (Davim, 2014; Wankat \& Oreovicz, 2015). However, in most areas and countries, the situation is still far from ideal, which causes issues such as school drop-out (Sabates, Westbrook, Akyeampong, \& Hunt, 2010), frustration (Zhang, Markopoulos, \& Bekker, n.d.), and lack of or surplus of professionals in some sectors (Stevens, Andrade, \& Page, 2016; Xue \& Larson, 2015). One example of these issues is the need for museums to increase visitor numbers in order to avoid their

Henry A. Colorado

henry.colorado@udea.edu.co

1 CCComposites Laboratory, Engineering School, Universidad de Antioquia UdeA, Calle $70 \mathrm{~N}^{\circ}$. 52-21, Medellín, Colombia

2 Museo Universitario-UdeA, Universidad de Antioquia, Medellín, Colombia collapse (Di Pietro, Guglielmetti Mugion, Renzi, \& Toni, 2014). In addition, there is a lack of environmental education in many countries, which could lead to species extinction and other related issues (Mauricio, Castellanos, Dios, \& Ortegon, n.d.). Another important consideration is the need for an inter and multi-disciplinarily education (Ullah, 2013) that gives students tools for facing subjects such as environmental issues or over population (Marques, 2008). For these reasons, the aim of this project is to investigate a multidisciplinary approach that involves active methods, arts, manufacturing of parts (via additive manufacturing), and experimental learning (Hajshirmohammadi, 2017). As such, the selected museum pieces were studied, manufactured, and presented to students in both a primary school and a university. A case study teaching method was initially considered central to this research because diverse case study methods can be developed around problem-based learning with a high level of student interaction through the case. However, later, a combined strategy was selected as described above, thereby not limiting the study to one methodology. The use of a discussion case method could be particularly appropriate for this investigation (Gomm, Hammersley, \& 
Foster, 2000; Grimes \& Warschauer, 2008), where students can actively cooperate with each other, thereby maximizing learning (Herreid, 2011; Tsay \& Brady, 2010).

Additive manufacturing (AM) or 3D printing (3DP) is significantly changing many fields in engineering, economics, arts, and education (Gibson, Rosen, \& Stucker, 2010). $\mathrm{AM}$ in particular is a very adaptable solution that is currently playing an important role in several of the world's key problems: environmental and economical sustainability, medicine, and education. In terms of environmental sustainability, AM has been used as an effective technique for rapid prototyping (Campbell, Bourell, \& Gibson, 2012) by optimizing the product design to reduce waste and contribute to a circular economy (Sauerwein, Doubrovski, Balkenende, \& Bakker, 2019). In medicine, AM has had a significant impact on the manufacturing of tissues and organs (Melchels et al., 2012), prosthesis (Chen, Jin, Wensman, \& Shih, 2016), and recently on the manufacturing of respiratory protection against coronavirus in the Covid-19 pandemic (Fleischer, Diehl, Wauben, \& Dankelman, 2020; Gates, 2020; Reich, 2020). In terms of production costs, economists consider AM to be an industrial revolution both for small-batch and mass production. All this has provided the setting for an intense debate about the real costs of AM and its impact on the environment (Atzeni \& Salmi, 2012; Baumers, Dickens, Tuck, \& Hague, 2016; Sun, Hua, Cheng, \& Wang, 2020; Walls, Corney, \& Annamalai Vasantha, 2014; Wittbrodt et al., 2013).

The educational model is in a constant process of evaluation and continually seeks new learning techniques. Therefore, any method that allows learning to be conducted through experiences will help the work of teachers and stimulate students in their learning.

Particularly in education, AM is introducing new methodologies and strategies that solve some of the deficits that teaching practice can have (Ford \& Minshall, 2019). It is providing new teaching practices which can be used as a powerful tool for manufacturing elsewhere. Because AM is very versatile, the technique has been explored in the teaching of different subjects, such as structural dynamics (Virgin, 2017), undergraduate and graduate degrees in manufacturing (Leary, Mazur, McMillan, Brandt, \& Subic, 2015; Stern, Rosenthal, Dresler, \& Ashkenazi, 2019), and multidisciplinary projects for training teachers in AM in a collaborative way (Schelly, Anzalone, Wijnen, \& Pearce, 2015). Of particular interest is the use of AM for the production of models and other types of anatomical materials. These can be used to teach biology and medicine where the use of dead bodies and dissection is inefficient, expensive, and sometimes impossible or considered unethical (Mcmenamin, Quayle, Mchenry, \& Adams, 2014). In areas such as archaeology, through models, AM is also having an important impact on the way students, teachers, and the general public interact with priceless artifacts that are impossible to interact with due to their cultural or scientific value (Reilly, 2015). Thus, museums and other organizations related to the preservation of cultural heritage are now starting to use AM as a way to preserve their collections and make them more accessible to students and the general public (Neumüller, Reichinger, Rist, $\&$ Kern, 2014). Being able to gain close access to artifacts is of course a more fruitful experience for visitors and also enables museums to promote their collections in real life instead of only in catalogues. The 3D scanning of a piece is typically the preliminary step before the 3DP process begins. This experience has also been identified to help enable sensitive groups, such as people with learning issues, children, the elderly, and the disabled to access knowledge (Neumüller et al., 2014).

On the other hand, deforestation and wildlife extinction are global problems (Ehrlich, Ceballos, \& García, 2010) which have multiple causes, such as the wrong economic model and overpopulation (Harari, 2018). The Amazonia region (which contains the large Amazon rainforest and covers several nations in South America: Brazil, Peru, Colombia, Venezuela, Ecuador, Bolivia, Guyana, and Suriname) is one of the last pristine regions of the planet that still has an abundant number of species and therefore represents a hope for future generations and requires immediate action to be taken to preserve it. AM can be a way to teach children about the local species in this region, and thus be a tool for learning not only about how the species look but also about how important they are to the community and the planet.

Students today are demanding a change in syllabus content to include more important social issues and megatrend challenges in teaching practice (Parker, Prabawa-Sear, \& Kustiningsih, 2018). They also require a varied style in teaching methods (Lujan \& Dicarlo, 2006), expressing that the teaching strategy, methodology, and tools all count in the learning process. In particular, active-based, project-based, teaching-based, inquiry-based, game-based, and case study learning methodologies have been the subject of intense research and practice in multiple areas (Konopka, Adaime, $\&$ Mosele, 2015), proving they are a good way to introduce students to practical subjects, including in museums (Boys, Hannan, Duhs, \& Chatterjee, 2019).

In this project, several animals were selected based on their importance in the community, their relatively unknown characteristics, and also because models of them can be found in the museum of the University of Antioquia. This provides the opportunity for a multidisciplinary project to be conducted involving areas such as education, engineering, biology, and arts. These species were also selected to emphasize their relationship with humans, which is sometimes underestimated. Thus, native species of bee, tardigrade, ant, and mosquito were selected based on the following considerations. First, it is well known that bee numbers are 
decreasing dramatically worldwide due to the uncontrolled use of harmful pesticides (Abramson, Aquino, Ramalho, \& Price, 1999), which could result in a lack of pollination and a consequent world famine. This is a worldwide problem, and although there is not much data about it in Colombia, the situation there may be even worse due to the number of pesticides used against illegal drug plantations. Such pesticides might even affect the chemistry of honey (Weinstock et al., 2006). On the contrary, tardigrades (or water bears) are microscopic animals well-known to be one the toughest species on earth able to survive the most extreme conditions, such as high vacuum, low temperatures, and lack of water and food (Tsukii, 2009). This animal has been identified as a bio-indicator (Vargha \& Tuba, 2002) of pollution and other environmental effects. The mosquito is perhaps the deadliest animal for humans, responsible for spreading numerous viruses and illnesses every year. It has been reported (Dupont-Rouzeyrol et al., 2015) that every year, dengue virus causes more than 50,000,000 cases, 500,000 hospitalizations, and 12,500 deaths worldwide. Part of the problem is that communities do not usually know much about this insect. Finally, ants are well known (Dauber \& Wolters, 2004) to be incredibly strong, collaborative and hardworking, which are desirable values in many communities.

Since the main goal of this research is to investigate a multidisciplinary method to educate people visiting the museum of the University of Antioquia, a strategy must be developed to motivate children and young people to learn about the local fauna using arts and engineering. Objectives include the use of an advanced manufacturing technique to show students from diverse areas about engineering, particularly materials and 3D printing; to explore active learning methods in different environments as a strategy to bring more people to the museum and to motivate people to learn; and to work in an interdisciplinary area that shows participants the relationship between different parts of a project. In order to fulfill these goals, a scanning apparatus was used to digitalize selected art pieces from a museum, which were later printed in a FFF (fused filament fabrication) apparatus using several materials. Scanning electron (SEM) and optical (OM) microscopies were used to characterize the local species. In addition, selected information was put on cards for the participants to read, and some artwork was included in the activities designed to fulfill the aforementioned objectives. Thus, 3D models, technical information, art pieces, and active learning methods were used to study the participants' response. Their experience interacting with this different information was recorded.

\section{Materials and Methods}

Three (3) animal specimens (ant, bee, and mosquito) found in the Natural Sciences collection of the museum of the University of Antioquia and one (1) animal (tardigrade) from a laboratory in the University of Antioquia's Institute of Biology were the focus of this work.

The general methodology followed in this research is summarized in Fig. 1. Three different types of information related to the artwork in the museum were presented to the participants who evaluated it using simple qualitative surveys. The arrows in the block diagram demonstrate that all three types of information were presented to the participants together to contribute to the learning activities.

The information was a sculpture, a museum piece, a 3D-printed model simulating the art piece in several sizes and materials and technical information cards related to the object. The selected artwork for the projects were small
Fig. 1 Block diagram of the method followed in this investigation

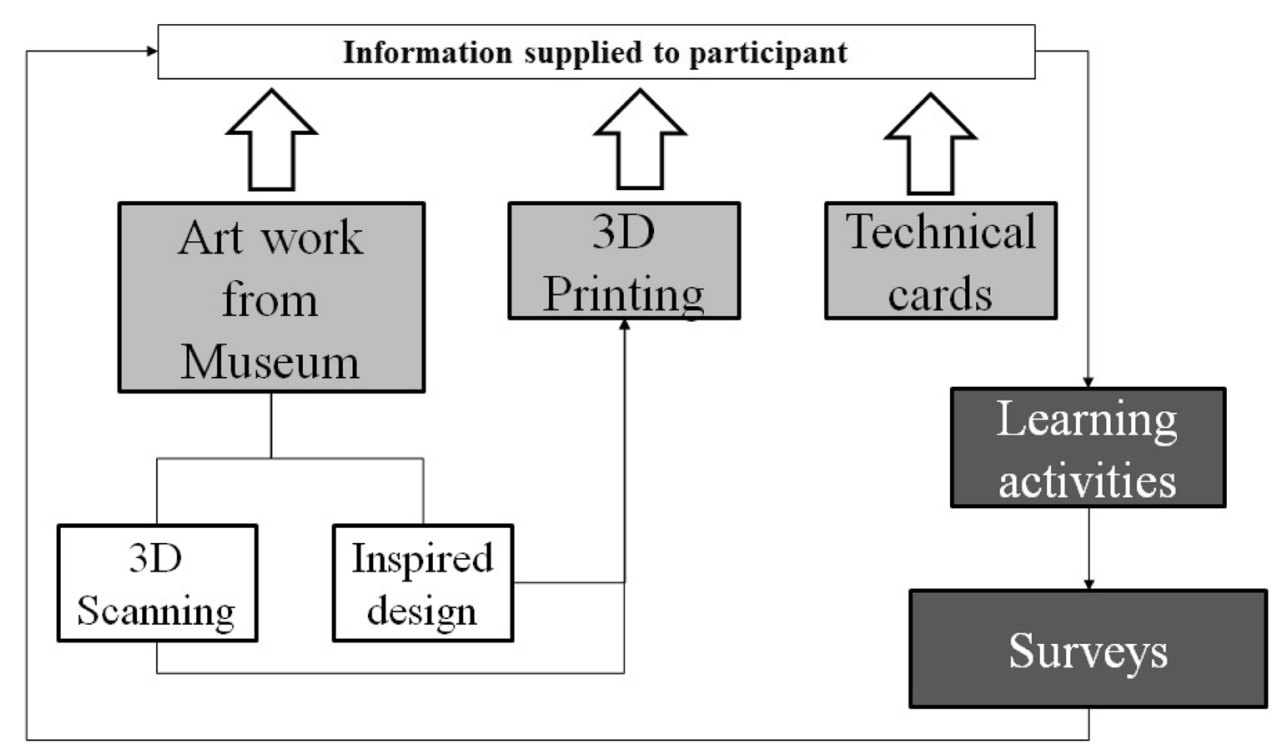


animal sculptures from the museum of the University of Antioquia made of balsa wood by biologist and artist A. Berrio in 2003 (see Fig. 2). The animals were also selected bearing in mind that their characteristics were relatively unknown to the local people (see Table 1). The animals were a native bee (Apis mellifera), a native water bear (tardigrade), a native ant (Formica spp), and a native mosquito (Aedes aegypti). The surveys were conducted during February which is the start of the academic year. They were physically delivered to the participants during the activity, with the help of auxiliary personnel.

The activity was expected to result in a higher percentage of people accepting 3D printing as a teaching and learning tool and the use of polymers to manufacture parts. Each animal was complemented with basic biological information, as well as other outstanding data, which was presented didactically on cards for greater understanding. The information about each animal was brief and of interest to all students. These activities were selected to try to simulate the environment of a real museum exhibition, where participants observe an exhibit and read important information about it close by. Audiovisual tools were used to enhance the interest and learning of the participants.

Some samples were designed starting from scratch using Autodesk Maya and Inventor, or a remodeling of other known designs from Thingiverse ("ThingiverseDigital Designs for Physical Objects," n.d.) as a base model, as shown in Fig. 3. In contrast, some samples were scanned, as shown in Fig. 4, and others were designed in full from museum insects. For the artwork, an EinScanPro + 3D scanner with $0.05 \mathrm{~mm}$ of single-shot accuracy was used. The CAD models obtained from each method (scanning or design) were prepared using an Ultimaker CURA slicer to create a g-code file. A cloned-modified Prusa with a $0.4-\mathrm{mm}$ nozzle, glass bed, and direct drive extrusion was used to print the models with PLA (polylactic acid) and TPU (thermoplastic polyurethane) (one print for each animal and material). Printing parameters and material properties are presented in Tables 2 and 3 respectively. With the parameters defined for PLA, the water bear required a smaller amount of material (total weight including support material) and time to print (without taking into account post-processing time) than the other pieces, weighing $25 \mathrm{~g}$ and taking $2 \mathrm{~h}$ and $50 \mathrm{~min}$. The mosquito weighed $30 \mathrm{~g}$ and took $3 \mathrm{~h}$ and $32 \mathrm{~min}$ to print, while the ant was $46 \mathrm{~g}$ and took $5 \mathrm{~h}$ and $15 \mathrm{~min}$. Finally, the bee weighted $112 \mathrm{~g}$ and took $14 \mathrm{~h}$ and $18 \mathrm{~min}$ to print. As for the TPU, the weight remained almost the same due to its similar density, while the printing times were doubled, as shown in Table 2.

In order to make the information more complete, scanning electron microscope (SEM) and optical microscopy images were included of real samples obtained from the museum and local research groups, all of which were local species. The SEM was a JEOL JSM 6700R used in high vacuum mode. Animals analyzed with microscopy were obtained as follows: the local bee from a collection in the university museum, the Formica spp ant, and water bear from the Biology Institute of the University of Antioquia, the mosquito from the PECET department for the study and control of tropical illness at the University of Antioquia. Each model was evaluated by biologists from the university museum to ensure there were no errors, and they were exactly like the real animals. The information about each animal was based on scientific data.

The surveys were carried out in a local high school, and other experiments were conducted with first year undergraduate students from the university. Models were shown to participants so they could play with them, touch them, and guess the type of materials and manufacturing process by filling out a survey. Thereafter, information cards, artwork, and a video of the full manufacturing process were presented to explain the project information. At the end, there was time for questions and discussion. The questions were answered by a teacher who was a specialist in the topic so that they could be evaluated accurately. After each model had been made, follow-up work was done to correct any errors in the print. The information was presented in an attractive way to aid understanding.

In addition, the costs for the production of the $3 \mathrm{D}$ printed models were estimated. The following data and specific considerations were taken into account for the calculation:
Fig. 2 Artwork of insects from Museo Universitario-UdeA (museum of the University of Antioquia) made of balsa wood by artist A. Berrio, 2003: a) several insects fabricated in balsa wood from the museum; b) ant made in balsa wood object of the present study
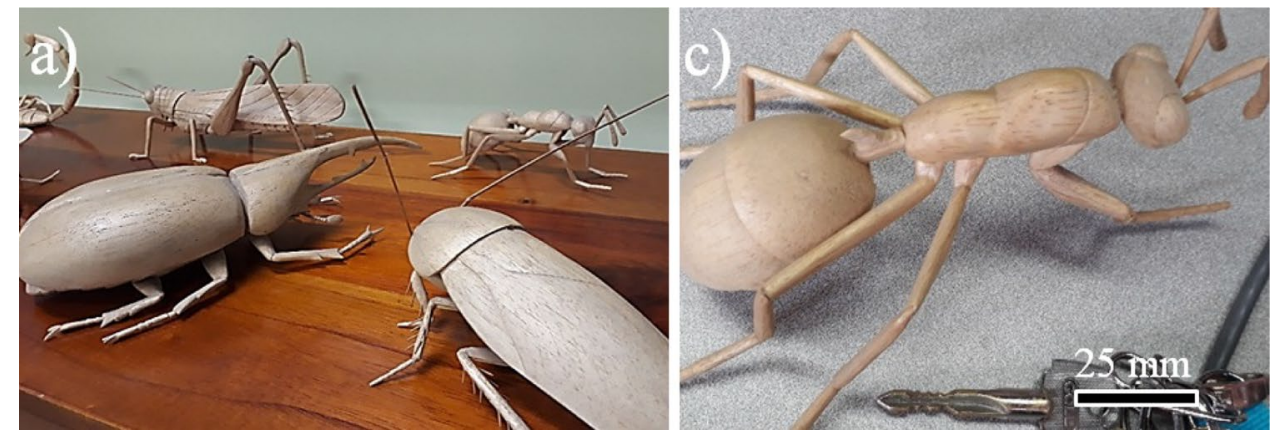


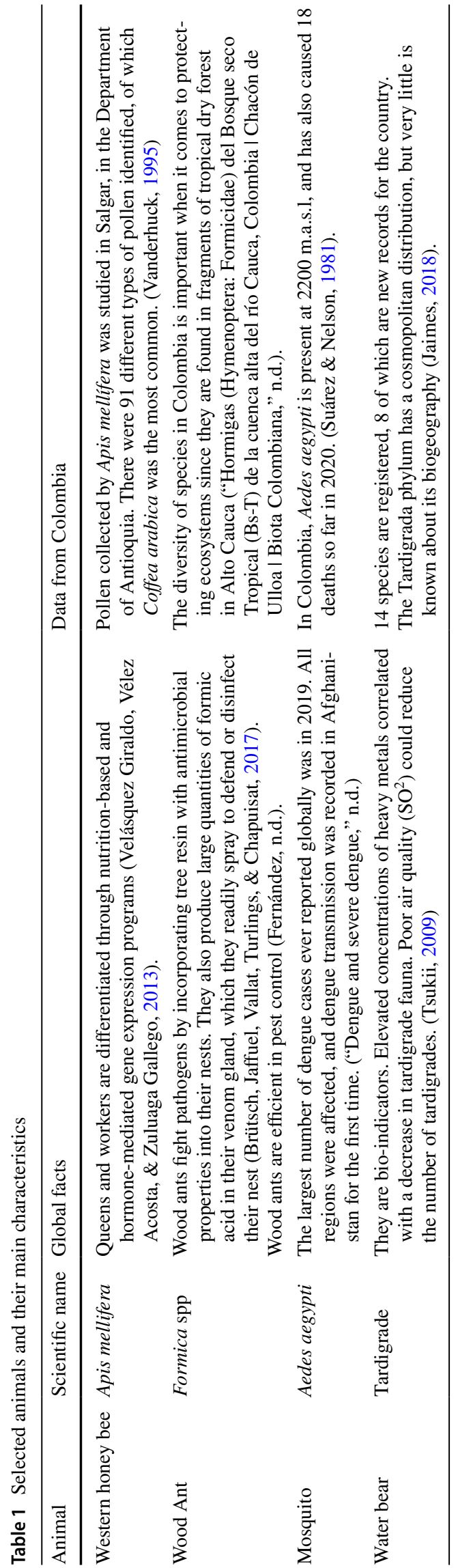

1 The 3D printer was already purchased.

2 No operator balance was taken into account.

3 The rent of the site was not taken into account.

4 The base energy consumption was $0.12 \mathrm{~kW}$ (Walls et al., 2014; Wittbrodt et al., 2013) with a cost of US $\$ 0.175 /$ $\mathrm{kWh}$ (COP $\$ 620 / \mathrm{kWh}$ according to EPM).

5 The average PLA price was US\$20/kg and TPU was US $\$ 25 / \mathrm{kg}$.

6 The percentages of profit, contingencies, and maintenance were $20 \%, 20 \%$, and $12 \%$ respectively.

The reason for defining these considerations was to obtain a final price that is more comparable with different situations, i.e., regardless of characteristics specific to a certain place such as salaries, logistics, equipment, and other variables. The calculated price will depend only on values where the variation between different situations is low (material cost, production times, and energy consumption).

\section{Results}

Each model was printed in various sizes and materials to find the most appropriate, resistant, and didactic size and material for teaching and student learning. The design obtained for each animal, including a preview of the slicing and scale of the final model, is presented in Fig. 3. Each row represents an animal, starting with the bee in Fig. 3a, then the mosquito in Fig. 3b, the ant in Fig. 3c, and finally the water bear in Fig. 3d. The design of the bee requires the wing and claws to be printed separately in order to give it a better finish and minimize material waste. A similar procedure was followed for the other animals. The mosquito consists of 3 printed parts: legs, wings, and body. It was particularly difficult to print the legs. The ant body was divided into two longitudinal parts. The legs and antennas were the most challenging pieces. The water bear shown in the figure was printed in 2 parts, as shown in the slicer preview.

Figure 4 shows the 3D scanning process for one of the art pieces, its slicing, and the 3D-printed model. An exact copy was created following the same method. Details of the surface, geometry, and scale of the original piece were copied. The model obtained was printed with PLA to ensure that it was as rigid as the original piece of wood and therefore closely represented the original object.

Figure $5 \mathrm{a}$ and $\mathrm{b}$ present images obtained using SEM to validate the design of the bee and the ant, respectively. For the bee, details of the head, connection between the head and the antenna, and the wing are shown. In the case of the ant, the complete body, the antenna, and the leg are shown. Figure $5 \mathrm{c}$ and $\mathrm{d}$ present images of the mosquito and the water bear produced using OM. These images confirm that 
Fig. 3 Stages of additive manufacturing process from the design and slicing process to the printed object. Remodeled from ("Thingiverse-Digital Designs for Physical Objects," n.d.): 3D models for the a) honey bee Apis mellifera: b) mosquito Aedes aegypti; c) ant formica spp; d) water bear Tardigrade

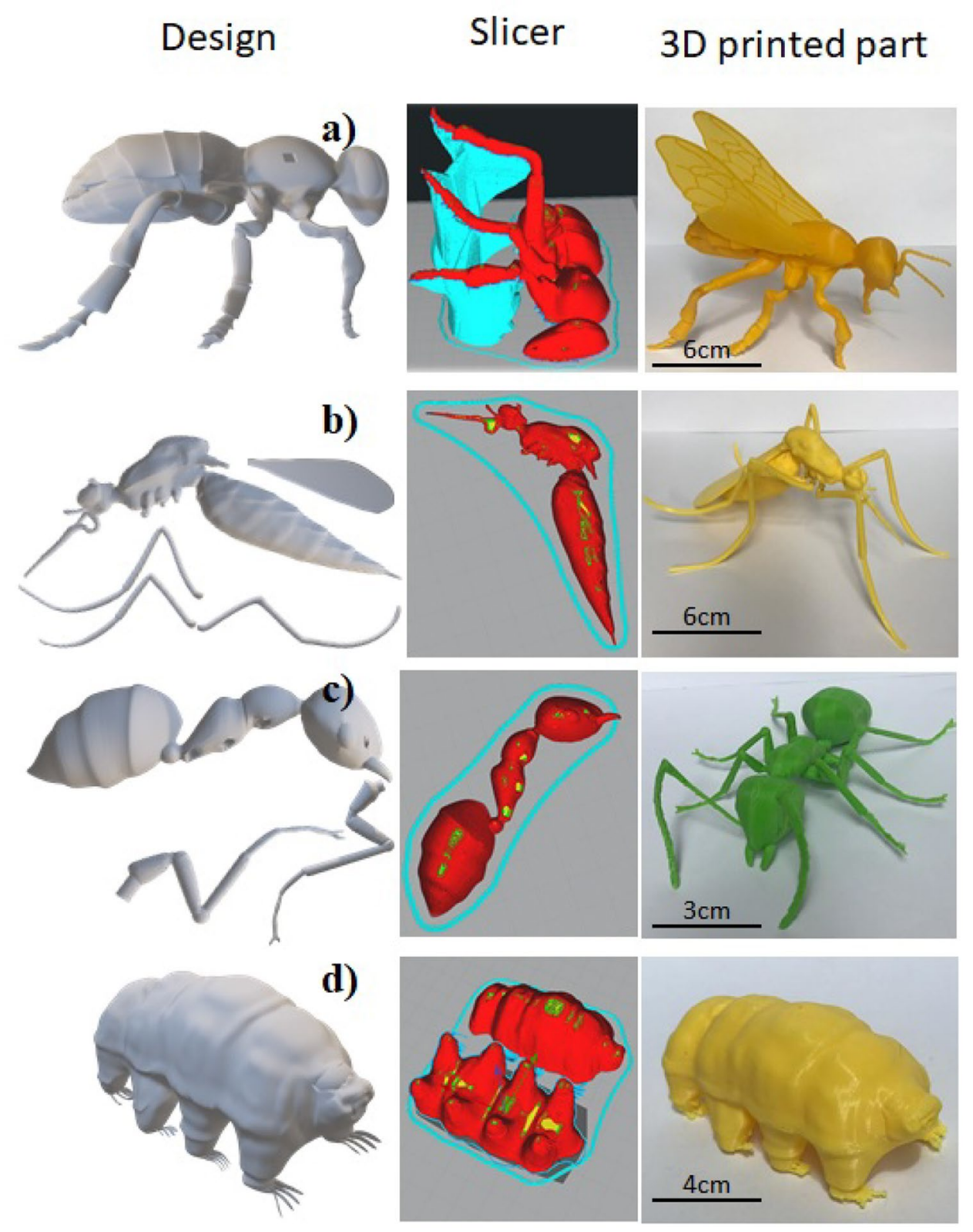

a) Art piece

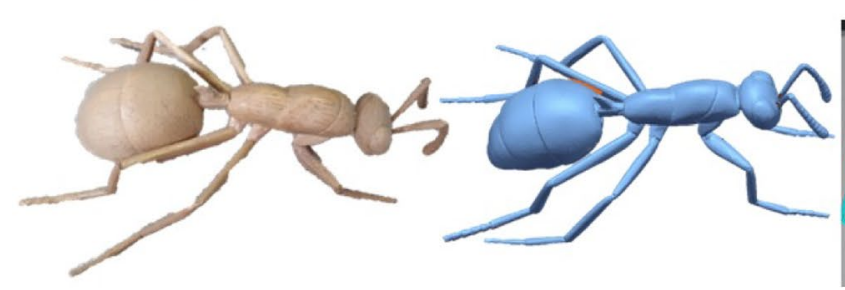

c) Slicing process

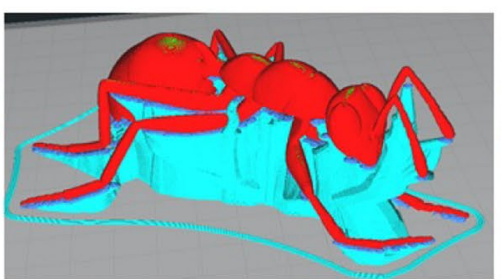

d) Printed part

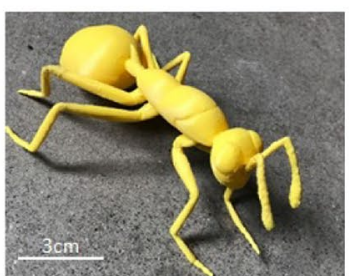

Fig. 4 Stages in the additive manufacturing process, from the scanning of artwork to producing a printed object used for educational purposes: a) Art piece; b) 3D scan; c) Slicing process; d) Printed part 
Table 2 Printing parameters for both materials

\begin{tabular}{lll}
\hline Parameter & Value (type) \\
\cline { 2 - 3 } Material & PLA & TPU \\
\hline Layer height & $0.16 \mathrm{~mm}$ & $0.2 \mathrm{~mm}$ \\
Infill & $15 \%$ (gyroid) & $15 \%$ (gyroid) \\
Speed & $40 \mathrm{~mm} / \mathrm{s}$ & $20 \mathrm{~mm} / \mathrm{s}$ \\
Support & Yes (tree support) & Yes (tree support) \\
\hline
\end{tabular}

the design details are correct and also establish limits to the manufacturing process.

The models obtained by 3D printing using PLA and TPU are shown in Fig. 6. All the figures show PLA rigid models have a good surface finish. They underwent some minor polishing post-processing such as plastic burr trimming, which can be used for the teaching and learning of artistic activities like painting the piece or any surface improvement in general. In the case of the TPU models, which are quite flexible, the white color does not allow many details to be seen. However, in addition to being convenient to handle and move around without damaging the piece, the color is an invitation for painting. This gives people the chance for real active interaction and a full experience, rather than just having a passive view of the piece in the museum. Even though some models were built by joining 3D-printed parts (wings, legs, antennas), it is almost impossible to see the joining interfaces. In fact, having modular parts can be a good strategy for people to build their own animal, which is another learning process.

Figure 7 shows screenshots of the video that describes the manufacturing process of the bee model. At $t=0 \mathrm{~min}$, the title of the activity is shown to reveal the manufacturing method; at $t=0.8 \mathrm{~min}$, the beginning of the design is shown in Autodesk Maya where real images function as a guide and show a simple shape being molded as the thorax of the animal. At $t=2.30 \mathrm{~min}$, the quality of the model mesh is shown for quality purposes, and finally, at $t=7.03 \mathrm{~min}$, the final design of the insect body is shown.
Figure 8 shows the information for each animal presented on four information cards made with Adobe Illustrator, one per animal, which summarize the following information: distribution, size, feeding, and other characteristics of the piece. In addition, each animal has special characteristics that are presented in the facts section, which has been identified as the most interesting section by the participants of the learning activities from Fig. 9.

\section{Teaching-Learning Activities}

The development of the activity is shown in Fig. 9. The first row presents the study carried out in a Primary School, while the second row shows the activity with first-year undergraduate students in the university. In all cases, the activity was the same, and all the participants actively interacted with the manufactured pieces and answered surveys. The activities include playing and examining the printed objects; watching a video presentation explaining the design, and slicing and printing processes; asking questions; and completing surveys, among others.

The surveys carried out in this project are shown in Figs. 10 and 11. Figure 10 a shows the results confirming the acceptance of $3 \mathrm{D}$ printing as the most motivating method for learning, with $88 \%$ votes by the first year undergraduate students, and very consistent votes for the younger ages: 77\% for students between 13 and 17 years old, and $81 \%$ for children between 6 and 12 years old. As shown in Fig. 10b, the technical card and the $3 \mathrm{D}$ object were both perceived as good methods for learning. The poorest perception of learning was clearly obtained for observation of the artwork, as expected. Figure $10 \mathrm{c}$ shows that the activity was perceived well, and it was in fact the first experience most students had of research, active learning, advance manufacturing, and, in the case of the children, university.

Some more technical questions were included in the surveys summarized in Fig. 11. Since the younger age groups have very limited knowledge regarding manufacturing, materials, and arts, these questions were only asked

Table 3 Typical material properties for both the art and pieces made by 3DP

\begin{tabular}{|c|c|c|c|c|}
\hline Material & $\begin{array}{l}\text { Part manu- } \\
\text { facturing } \\
\text { Process }\end{array}$ & Elastic modulus (GPa) & Tensile strength (MPa) & $\begin{array}{l}\text { Density } \\
\left(\mathrm{g} / \mathrm{cm}^{3}\right)\end{array}$ \\
\hline BALSA wood & Art, sculpture & 9 (Borrega \& Gibson, 2015) & $\begin{array}{l}43 \mathrm{MPa} \\
\text { (Compresive strength) } \\
\text { (Borrega \& Gibson, } \\
\text { 2015) }\end{array}$ & $\begin{array}{l}\left(60-380 \frac{\mathrm{kg}}{\mathrm{m}^{3}}\right) \\
\text { (Borrega \& Gibson, 2015) }\end{array}$ \\
\hline PLA & $3 \mathrm{D}$ printing & 3 (Cong, 2007) & 50-70 (Cong, 2007) & $\begin{array}{l}1.24 \text { ("PLA density—what is the density of } \\
\text { PLA filament/plastic? | All3DP," n.d.) }\end{array}$ \\
\hline TPU & $3 \mathrm{D}$ printing & $\begin{array}{l}0.483-5.5 \text { ("Overview of materials for } \\
\text { thermoplastic polyurethane, elastomer, } \\
\text { glass filled," n.d.) }\end{array}$ & $\begin{array}{l}40 \text { (“TPU } 1.75-\mathrm{mm} \\
\text { 3D printer filament," } \\
\text { n.d.) }\end{array}$ & $\begin{array}{l}\text { 1.21(“TPU } 1.75-\mathrm{mm} 3 \mathrm{D} \text { printer filament," } \\
\text { n.d.) }\end{array}$ \\
\hline
\end{tabular}


Fig. 5 Examples of microscopy characterization of the animal selected in this research. a SEM images for the bee. b SEM images for the Formica spp wood ant. c OM image for the Aedes aegypti mosquito. d OM for the tardigrade captured in the University of Antioquia
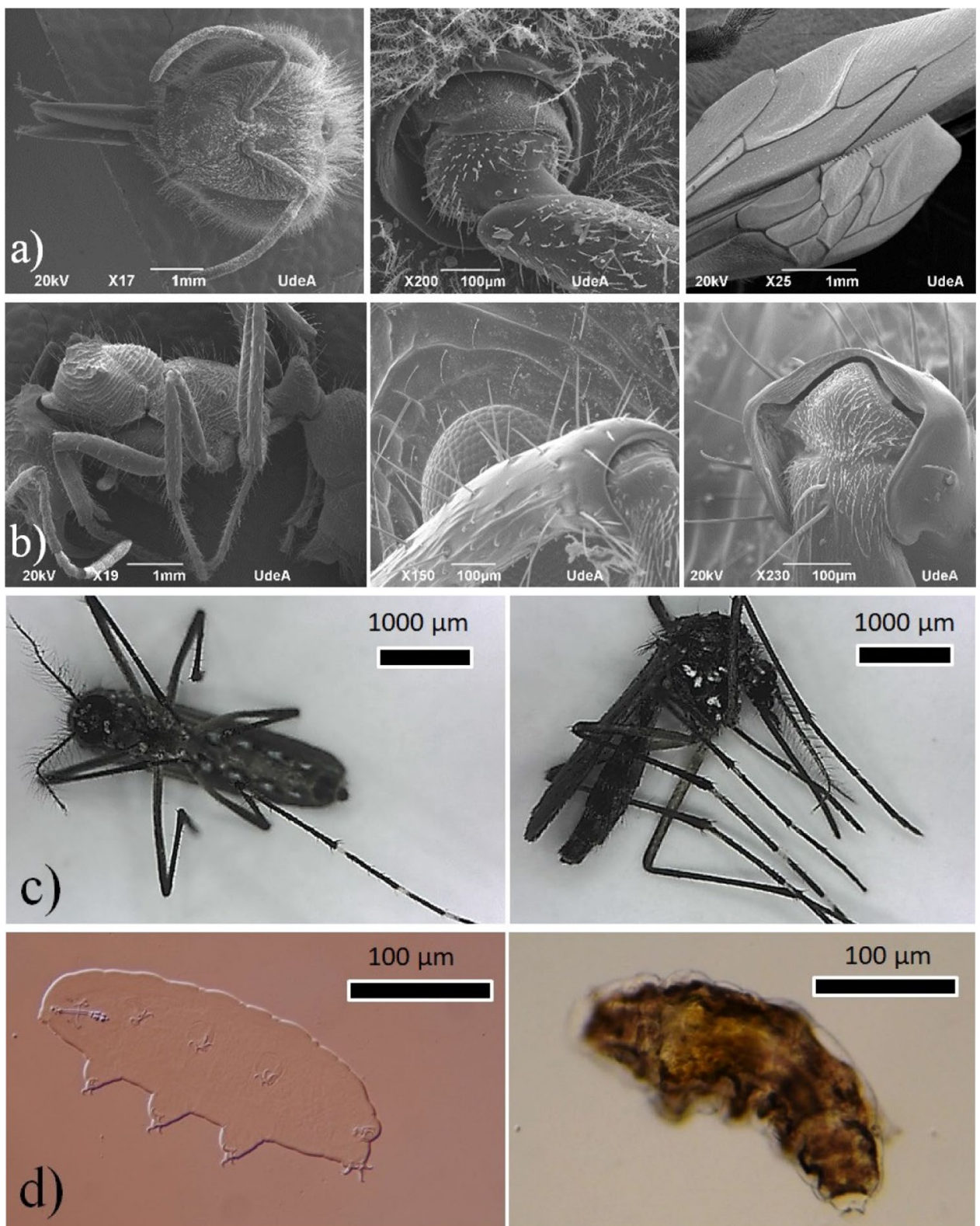

to the first year undergraduate students. In fact, Fig. 11a shows a general lack of knowledge in classrooms about manufacturing by $3 \mathrm{D}$ printing, as only $55 \%$ of respondents answered the question about the manufacturing process correctly. This is an indicator that information about this emerging technology has not been fully incorporated into education before and at the beginning of university. Figure $11 \mathrm{~b}$ shows a more positive result, with $83 \%$ of the respondents correctly answering the question about using polymers as building materials. It is worth noting that some people mentioned ceramics, metal castings, and even wax as possible building materials, which are very far from the real materials used in this project.

\section{Costs}

Table 4 presents the estimated costs for the 3D-printed models. The water bear model has the lowest cost at $\$ 5$ for the PLA and $\$ 8$ for the TPU materials. This is associated with its smaller size, geometry, and printing simplicity, which thereby avoids the need to use supporting material when compared with the other models. The honeybee costs $\$ 10$ for PLA and $\$ 16$ for TPU and the mosquito costs \$9 for PLA and \$13 for TPU. The ant model had very similar prices, with $\$ 8$ for PLA and $\$ 13$ for TPU materials. The variations in price are mainly due to the complexity of the parts, and also the way the models were separated into parts to make the printing process feasible. The honeybee model had its legs already attached to the body 
Fig. 6 Printed animals showing the materials used in this research: a PLA and $\mathbf{b}$ TPU

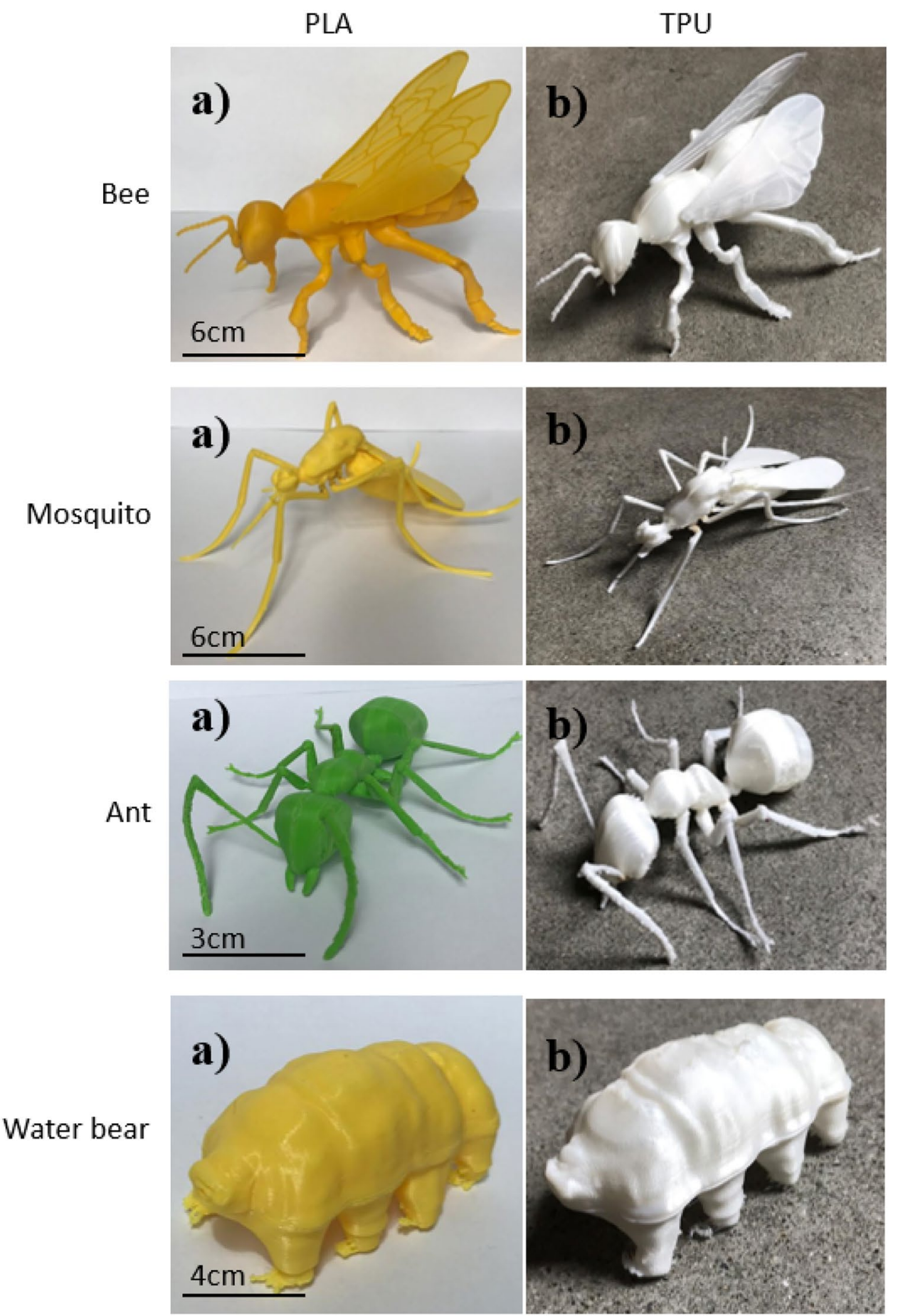

unlike the ant and the mosquito, which reduced the amount of material used and printing time.

\section{Discussion}

From a materials and manufacturing point of view, there were many challenges when building the pieces, from the surface finish, printing direction, material parameters, and machine resolution, to the design of acceptable animals from the original artwork given by the museum. The stiffness, weight, and strength of the printed animals mean there are many processing parameters that can be changed in order to adapt the pieces for different teaching activities. Such parameters include variation in the filling, removable parts, material properties, and more. Examples of the many possibilities for learning are the fact that one piece was rigid simulating wood, and the other was totally 

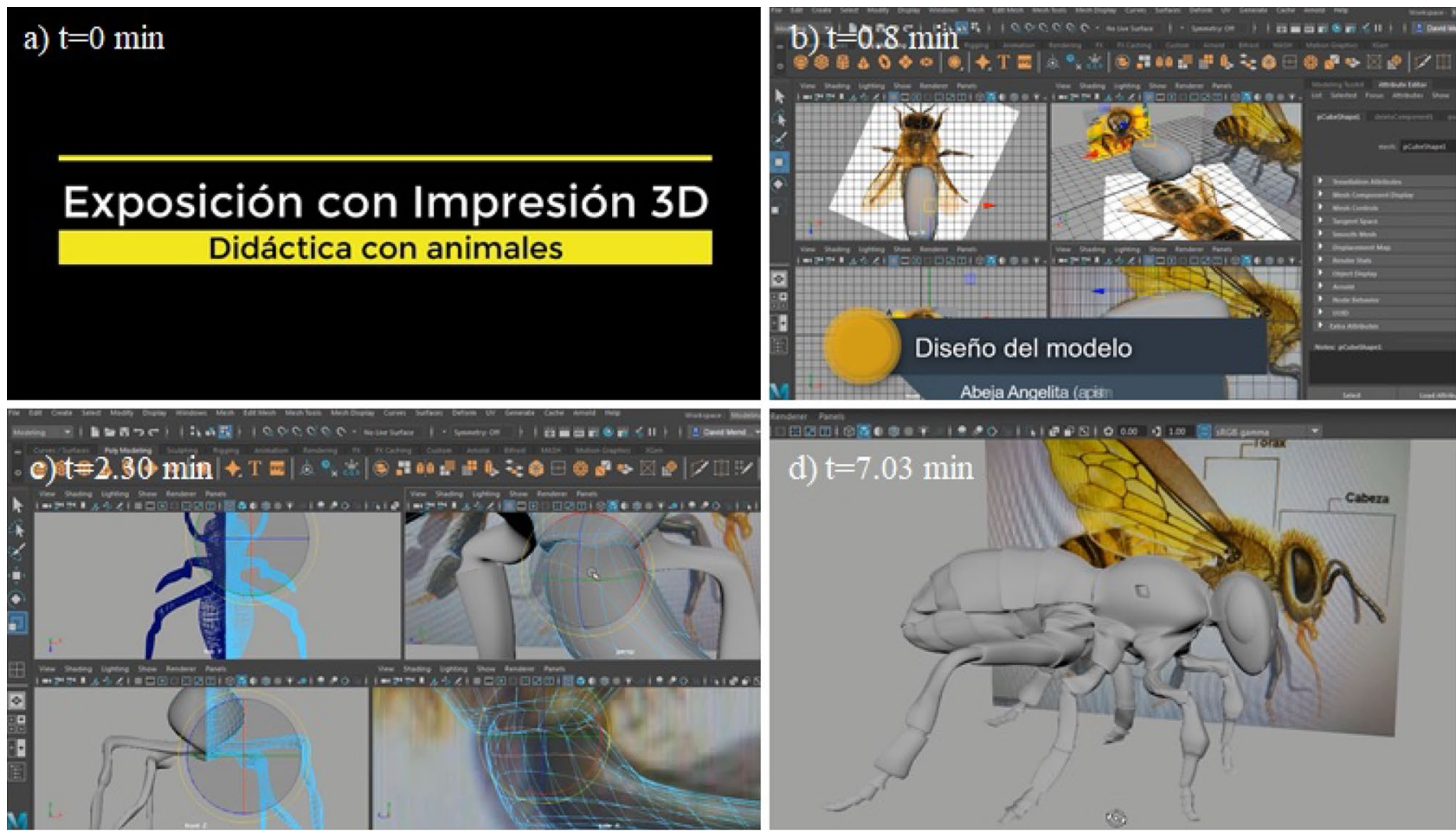

Fig. 7 Snap shots of a video of the complete manufacturing process presented in the museum, the elementary school and the university: a) Title slide in the original language (talk with 3D printing: didactic

flexible to allow more maneuverability for people interacting with pieces.

The results presented in this project can have a significant impact in countries where the educational system mostly works with traditional teaching methodologies. Areas such as product design, which are needed in many sectors, motivate people in career selection and entrepreneurship and stimulate creativity in children. Additive manufacturing has shown to be one of the best tools to captivate students and encourage people to be creative, and thus, it complements the field of education well (Thompson et al., 2016). In most museums worldwide, the interaction of visitors with artwork or exhibits is quite limited, and this project has shown that different ages prefer a combination of information and activities. Students with spatial and physical disabilities may be particularly benefited by the implementation of this project in museums. It is well known that similar strategies involving active learning in museums have had very positive results (Boys et al., 2019). Countries can use this as an initiative to increase people's motivation to apply for STEAM (science-technology-engineering-arts-mathematics) careers, a critical issue which means many countries face a shortage of engineers (Blau, 2011). Strategies that have been reported include using AM to motivate and encourage positive participation in high school students by having them make objects that interest them (Akundi, Tseng, \& Saavedra, with animals) at $\mathrm{t}=0 \mathrm{~min}$; $\mathrm{b}$ ) detail at $\mathrm{t}=0.8 \mathrm{~min}$; ) detail at $\mathrm{t}=2.30$ $\min$; d) detail at $\mathrm{t}=7.03 \mathrm{~min}$

2015), successful AM training for teachers (Schelly et al., 2015), and multidisciplinary creativity based courses using AM (Stern et al., 2019), among many others. Education in museums worldwide is also undergoing a revolution, as they attempt to create virtual environments, use art therapy for complicated health problems (Peacock, 2012), and encourage creativity (Neumüller et al., 2014). All these aspects can be demonstrated in the current project. To create models similar to the real animals, work must be coordinated among all fields of knowledge, using both engineers and biologists.

On the other hand, teaching biology and other natural sciences using AM has been investigated before and drawn very positive conclusions regarding student learning (Capel, Rimington, Lewis, \& Christie, 2018; Mcmenamin et al., 2014). From a fauna and environmental perspective, participants' perception of the animals investigated in this project was very different before and after the active experience presented here, which was due to their lack of knowledge before the study. This research therefore has a significant impact on how people see the extinction of animals and flora. The bee (Apis mellifera) has an important role in pollination and the ecosystem, as presented in Table 1, which directly affects humans. Ants represent teamwork and also play an important role in the ecosystem. The water bear is the world's most resistant animal and is not as well known even today. Perhaps it is for this 
Fig. 8 Technical information cards showing data about the animals selected in this study
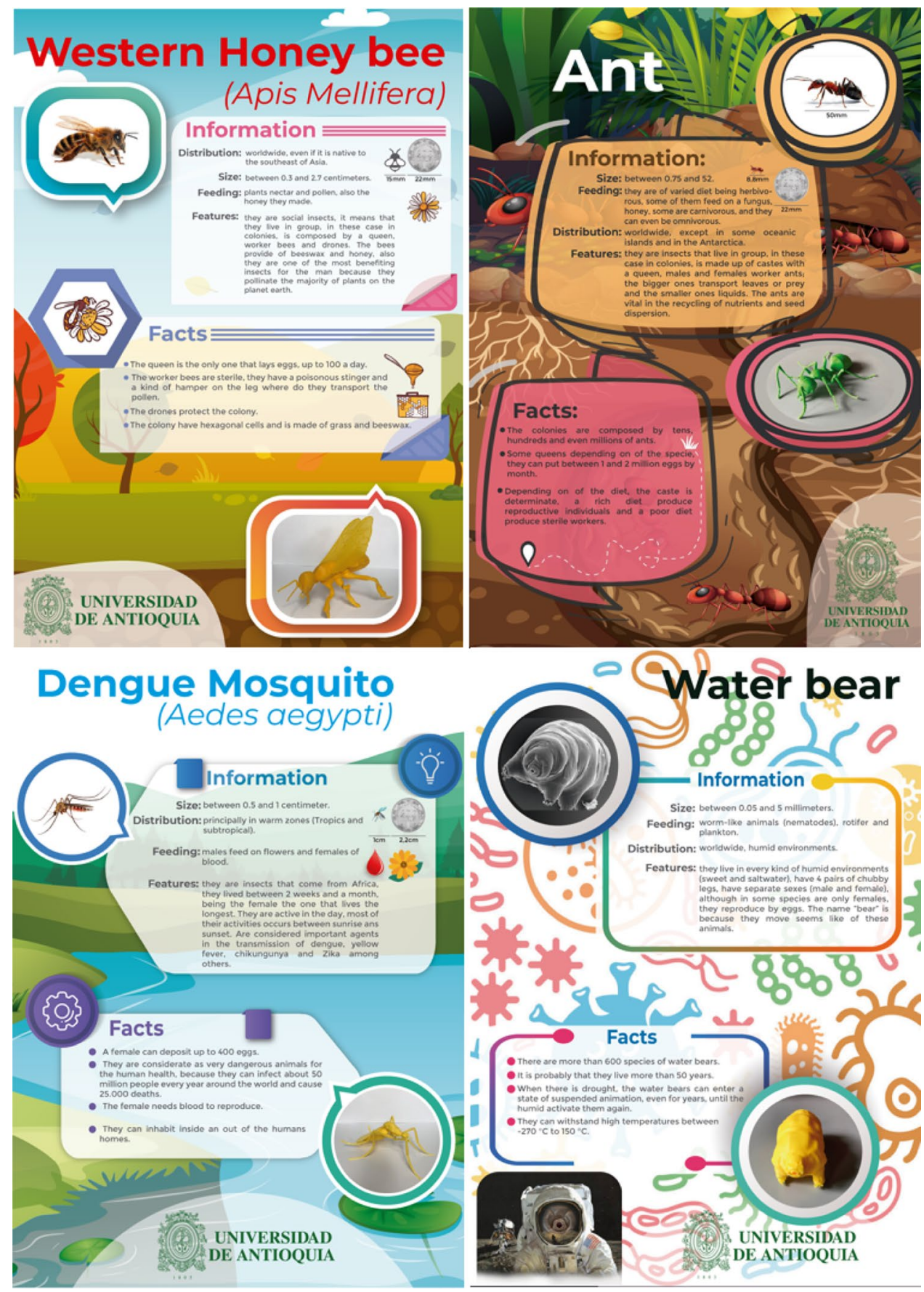

reason and its unfamiliar shape that it is the animal students were most drawn to. The animals mentioned here play an important role in human life, and the education provided is important to preserve these species and others. Moreover, from a public health point of view, health education in dengue (Madeira, Macharelli, Pedras, \& Delfino, 2002), malaria (Ghosh, Patil, Tiwari, \& Dash, 2006), and other diseases prevalent in the community is an essential strategy for prevention. Therefore, the use of AM models in remote areas can greatly support community education.
The surveys have shown there is a lack of knowledge in topics related to engineering. This research also shows that 3D printing is a complementary technique that can be used to improve teaching in all areas. There have been different studies that present positive survey results regarding $3 \mathrm{D}$ printing, such as a program that stimulated student interest in pursuing careers in science, design, and engineering (Ford \& Minshall, 2019).

An observation made during this project was that printed animal models are on a larger scale than their actual size. 
Fig. 9 Images of the activity being carried out with $\mathbf{a}-\mathbf{c}$ elementary school students, and $\mathbf{d}-\mathbf{f}$ first year engineering students
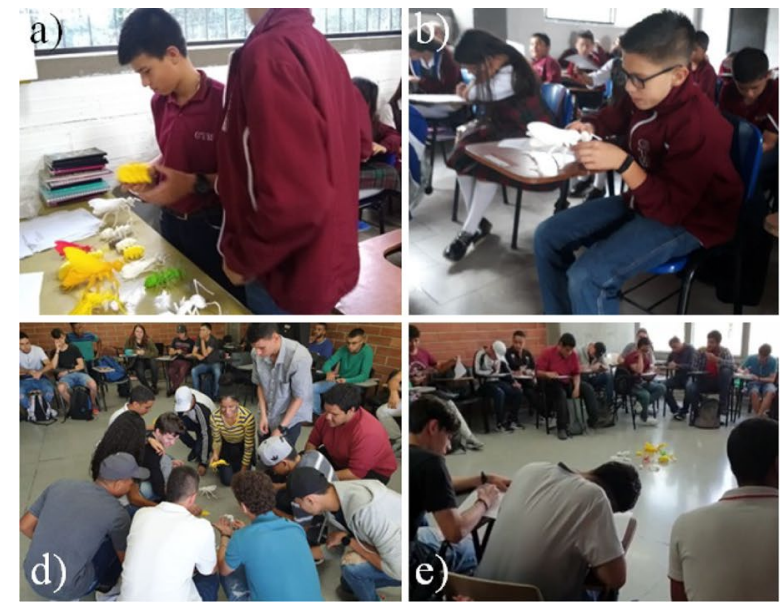

a) Which piece was more motivating?

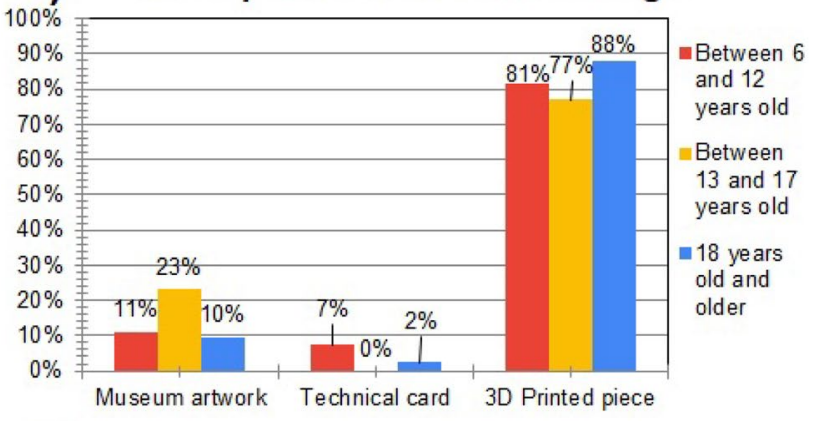

b) From which piece did you learn more?

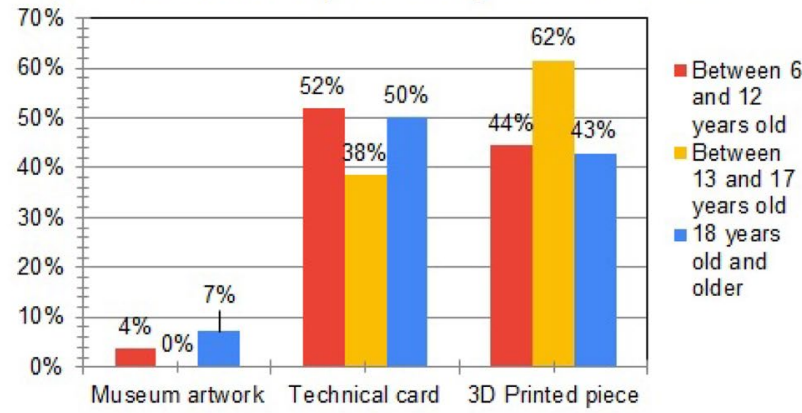

\section{C) What did you think about the activity?}

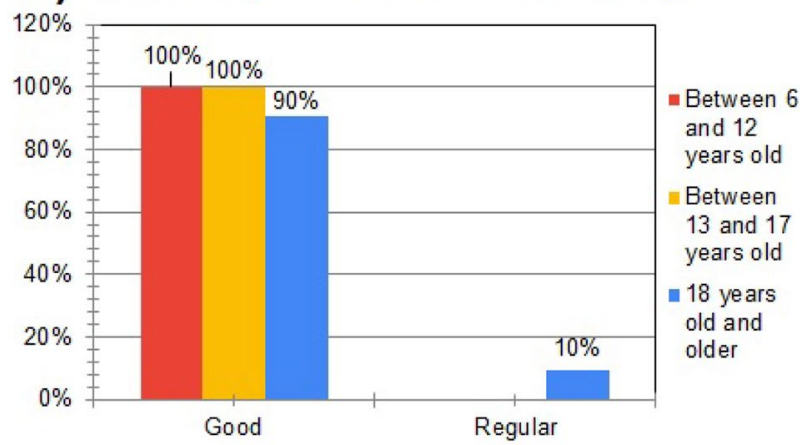

Fig. 10 Surveys by 3 different age groups involved in the learning activities: a) which piece was more motivating?; b) from which piece did you learn more?; c) what did you think about the activity?
This attracted the attention of students and demonstrates an increase in their curiosity and a greater interest in acquiring new knowledge. They were motivated by seeing an originally very tiny animal made on a scale observable to the naked eye. Certainly, this can be further used as a teaching and learning strategy for motivating students not only in the museum but also in their classrooms.

Finally, during this investigation, several difficulties arose in the different stages of the process. Some of these issues interfered with the study more than others, and if they had not been corrected, it would not have been possible to obtain the same results. It was found that using normal supports greatly interfered with the piece. This made post-processing noticeably difficult since there were very thin parts that could come off along with the support. Furthermore, the use of high-speed printing was only possible where there was a large cross-sectional area such as the torso of the animals. In the remaining parts, only low speeds were possible. The post-processing of models has limitations due to the geometry and nature of the material. The surface finish with sand paper was easier for PLA than for TPU, although in both materials, some parts of the animals were difficult to process mostly due to their complex geometry or small cross sections.

\section{Conclusions}

- This research has shown that 3D printing of pieces related to science, heritage, and culture is a good strategy not only for preserving artwork but also for teaching science and engineering.

- 3D scanning proved to be an excellent way to preserve heritage by creating identical copies of a museum piece so that people can interact with the model without damaging the original piece of art. 


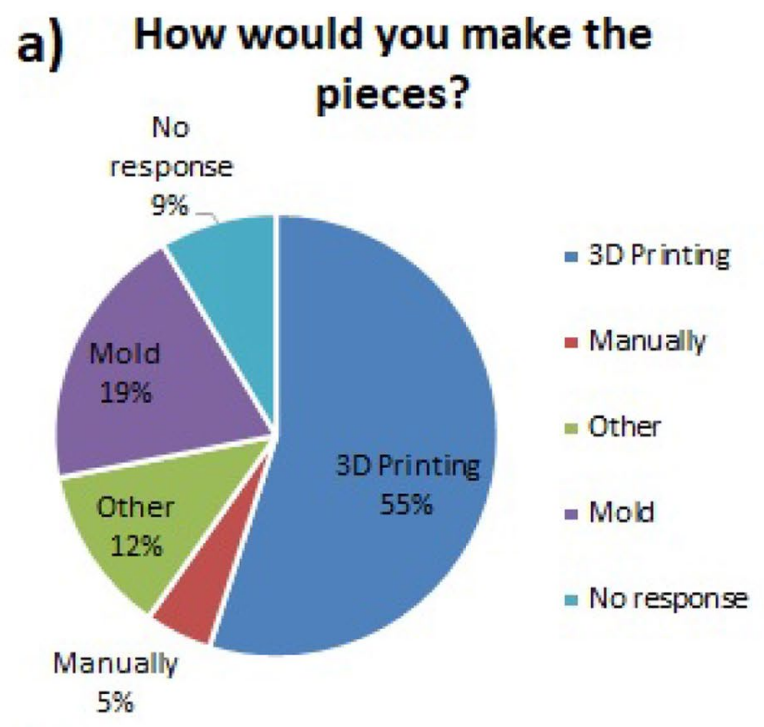

b) What material do you think was

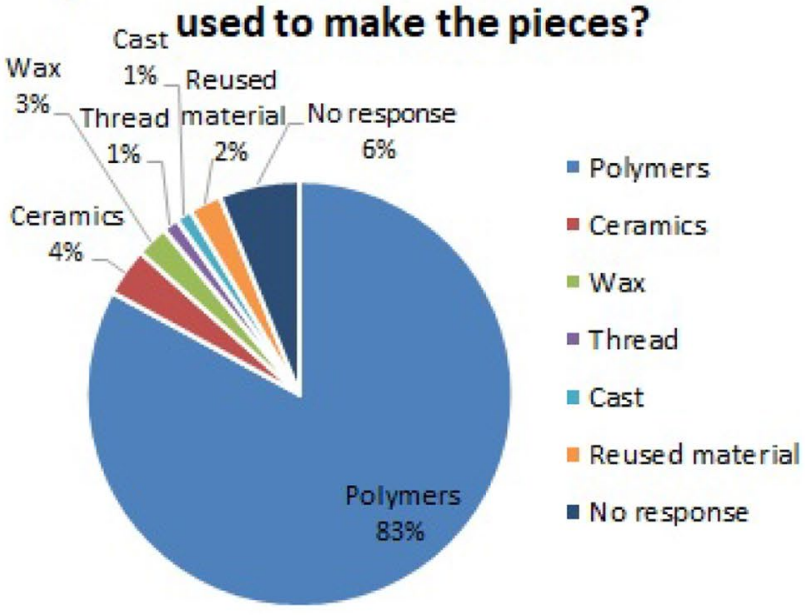

\section{c) What manufacturing process do} you think was used?

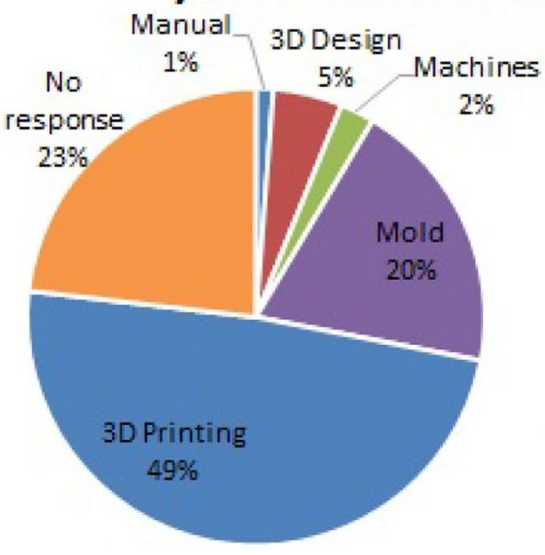

- Manual

- 3D Design

- Machines

- Mold

- 3DPrinting

- No response

Fig. 11 Technical questions: a) how would you make the pieces?; b) what material do you think was used to make the pieces?; c) what manufacturing process do you think was used?
Table 4 Comparison of the production costs of the 3D printed models

\begin{tabular}{lll}
\hline COSTS & \multicolumn{2}{l}{ Material (USD) } \\
\cline { 2 - 3 } Model & PLA & TPU \\
\hline Western honey bee & $\$ 10$ & $\$ 16$ \\
Water bear & $\$ 5$ & $\$ 8$ \\
Yellow fever mosquito & $\$ 9$ & $\$ 13$ \\
Ant & $\$ 8$ & $\$ 13$ \\
\hline
\end{tabular}

- Creating models in 3D is a huge support to the museum as it protects the original pieces and at the same time creates an interactive relationship between the exhibits and the visitors.

- In terms of education, this research has shown that a combination of 3D-printed models and (animal) model information works best to complement the learning processes. A total of $95.1 \%$ of the respondents preferred one of these options. In addition, the same percentage of people accepted the use of 3D printing in these areas as a didactic methodology.

- PLA material is not only economical as shown in the cost analysis but also recyclable and easy to print. Therefore, the process is sustainable and educational, which meets the original objectives of the project.

- TPU is a good alternative when the end use requires constant handling and risks possible bumps that can damage the model, but it is more expensive and difficult to print than PLA. Having analyzed the costs, its use in certain applications can be justified and recommended.

- 3D models are a useful tool for pedagogy since they can be printed on a large scale. Therefore, in the case of small or microscopic animals, it is possible to employ more didactic knowledge appropriation methodologies to teach the students.

- 3D model printing helps to avoid harm to animals because studies can be done on synthetic models.

Acknowledgments The authors of this project acknowledge Rectoría and Vicerrectoría de Extension from Universidad de Antioquia for the full support to this project. Also, thanks are due to Mr. Juan M. Perdomo for his comments in shaping part of this research. Special thanks to Teacher Alvaro Tangarife from Escuela Tercer Milenio for facilitating the surveys to his lovely students and to Prof Freddy Ruiz, Prof Mario Londoño, and Dr Gabriel Marín for kindly supplying some of the animal species included in this project.

Funding Rectoría and Vicerrectoría de Extension from Universidad de Antioquia provided the full support to this project.

\section{Compliance with Ethical Standards Statement}

Conflicts of Interest The authors declare that they have no conflict of interest. 
Ethical Statement The authors have followed all the ethical practices during this investigation and in the submission process.

Consent Statement All the participants in this research were informed that participation in the activities was on a voluntary basis, and they were never put in risk or identified individually in any part of the process. In the case of children, the corresponding permissions were arranged with the principal of the institution and its teachers by following Colombian bylaws. In all cases, the surveys were anonymous, and all the activities were fully explained. Questions about the process from any participant could be answered during any part of the process.

The use of animals in research and education: this research involved the observation of four animal species under the microscope; three were stuffed insects and one was live. Two of them, the ant and bee, belong to the university museum and are from an old collection compiled in Colombia. The mosquito was supplied by a Lab at the University of Antioquia. The water bear was alive and observed under an optical microscope without causing any harm. No animals suffered any damage or mistreatment, and the research followed the university, national, and international regulations for animal research. In addition, this research aims to positively impact the conservation of all these animals. The groups mentioned above have permission to collect the species involved in this study.

\section{References}

Abramson, C. I., Aquino, I. S., Ramalho, F. S., \& Price, J. M. (1999). The effect of insecticides on learning in the Africanized honey bee (Apis mellifera L.). Archives of Environmental Contamination and Toxicology, 37(4), 529-535. https://doi.org/10.1007/ s002449900548

Akundi, A., Tseng, B., \& Saavedra, J. (2015). Augmenting High School Student Interest in STEM Education Using Advanced Manufacturing Technology Bulk Piezoelectric and Dielectric Ceramics using Paste Extrusion 3D Printing Technique View project Information Entropy Applied to Complex Systems View project. https://doi. org $/ 10.18260 / \mathrm{p} .23608$

Atzeni, E., \& Salmi, A. (2012). Economics of additive manufacturing for end-usable metal parts. International Journal of Advanced Manufacturing Technology, 62(9-12), 1147-1155. https://doi. org/10.1007/s00170-011-3878-1

Baumers, M., Dickens, P., Tuck, C., \& Hague, R. (2016). The cost of additive manufacturing: Machine productivity, economies of scale and technology-push. Technological Forecasting and Social Change, 102, 193-201. https://doi.org/10.1016/j.techf ore.2015.02.015

Blau, J. (2011). Germany faces a shortage of engineers. IEEE Spectrum, 48(9), 16-18. https://doi.org/10.1109/mspec.2011.5995883

Borrega, M., \& Gibson, L. J. (2015). Mechanics of balsa (Ochroma pyramidale) wood. Mechanics of Materials, 84, 75-90. https:// doi.org/10.1016/j.mechmat.2015.01.014

Boys, J., Hannan, L., Duhs, R., \& Chatterjee, H. (2019). Object-Based Learning: A Powerful Pedagogy for Higher Education. In Museums and Higher Education Working Together (pp. 159-168). https://doi.org/10.4324/9781315596471-15

Brütsch, T., Jaffuel, G., Vallat, A., Turlings, T. C. J., \& Chapuisat, M. (2017). Wood ants produce a potent antimicrobial agent by applying formic acid on tree-collected resin. Ecology and Evolution, 7(7), 2249-2254. https://doi.org/10.1002/ece3.2834

Campbell, I., Bourell, D., \& Gibson, I. (2012). Additive manufacturing: rapid prototyping comes of age. Rapid Prototyping Journal, 18(4), 255-258. https://doi.org/10.1108/13552541211231563
Capel, A. J., Rimington, R. P., Lewis, M. P., \& Christie, S. D. R. (2018). 3D printing for chemical, pharmaceutical and biological applications. Nature Reviews Chemistry, 2, 422-436. https://doi. org/10.1038/s41570-018-0058-y

Chen, R. K., Jin, Y., \& an, Wensman, J., \& Shih, A. (2016). Additive manufacturing of custom orthoses and prostheses-A review. Additive Manufacturing, 12, (77-89). https://doi.org/10.1016/j. addma.2016.04.002

Cong, S. (2007). Properties of polylactic acid fiber based polymers and their correlation with composition. Proceedings of 2007 International Conference on Advanced Fibers and Polymer Materials. ICAFPM 2007, 1, 8-11.

Dauber, J., \& Wolters, V. (2004). Edge effects on ant community structure and species richness in an agricultural landscape. Biodiversity and Conservation, 13(5), 901-915. https://doi. org/10.1023/B:BIOC.0000014460.65462.2b

Davim, J. P. (2014). Engineering Education: Curriculum, Pedagogy and Didactic Aspects. Retrieved from https://books.google.com. co/books?id=UnfIAwAAQBAJ

Dengue and severe dengue. (n.d.). Retrieved March 31, 2020, from https://www.who.int/news-room/fact-sheets/detail/dengue-andsevere-dengue

Di Pietro, L., Guglielmetti Mugion, R., Renzi, M., \& Toni, M. (2014). An Audience-Centric Approach for Museums Sustainability. Sustainability, 6(9), 5745-5762. https://doi.org/10.3390/ su6095745

Dupont-Rouzeyrol, M., O’Connor, O., Calvez, E., Daures, M., John, M., Grangeon, J. P., \& Gourinat, A. C. (2015). Co-infection with zika and dengue viruses in 2 patients, New Caledonia, 2014. Emerging Infectious Diseases, 21, (pp. 381-382). https://doi. org/10.3201/eid2102.141553

Ehrlich, P. R., Ceballos, G., \& García, A. (2010). The Sixth Extinction Crisis Loss of Animal Populations and Species. In JournalofCosmology.com (Vol. 8). Retrieved from https://www. researchgate.net/publication/266231196

Fernández, F. (n.d.). Introducción a las hormigas de la región Neotropical.

Fleischer, J. C., Diehl, J. C., Wauben, L. S. G. L., \& Dankelman, J. (2020). The Effect of Chemical Cleaning on Mechanical Properties of Three-Dimensional Printed Polylactic Acid. Journal of Medical Devices, 14(1). https://doi.org/10.1115/1.4046120

Ford, S., \& Minshall, T. (2019). Invited review article: Where and how $3 \mathrm{D}$ printing is used in teaching and education. Additive Manufacturing, 25, 131-150. https://doi.org/10.1016/j.addma .2018 .10 .028

Gates, B. (2020). Responding to Covid-19 - A once-in-a-Century Pandemic? New England Journal of Medicine. https://doi. org/10.1056/nejmp2003762

Ghosh, S. K., Patil, R. R., Tiwari, S., \& Dash, A. P. (2006). A community-based health education programme for bio-environmental control of malaria through folk theatre (Kalajatha) in rural India. Malaria Journal, 5(1), 1-7. https://doi. org/10.1186/1475-2875-5-123

Gibson, I., Rosen, D. W., \& Stucker, B. (2010). Additive Manufacturing Technologies. Retrieved from https://books.google.com.co/books $? \mathrm{id}=$ BrYCswEACAAJ

Gomm, R., Hammersley, M., \& Foster, P. (2000). Case Study Method: Key Issues, Key Texts. Retrieved from https://books.google.com. co/books?id=cs7yAwAAQBAJ

Grimes, D., \& Warschauer, M. (2008). Learning with Laptops: A Multi-Method Case Study. Journal of Educational Computing Research, 38(3), 305-332. https://doi.org/10.2190/EC.38.3.d

Hajshirmohammadi, A. (2017). Incorporating Experiential Learning in Engineering Courses. IEEE Communications Magazine, 55(11), 166-169. https://doi.org/10.1109/MCOM.2017.1700373

Harari, Y. N. (2018). A brief history of humankind. (858), 4724. 
Herreid, C. F. (2011). Case study teaching. New Directions for Teaching and Learning, 2011(128), 31-40. https://doi.org/10.1002/ tl. 466

Hormigas (Hymenoptera: Formicidae) del Bosque seco Tropical (BsT) de la cuenca alta del río Cauca, Colombia I Chacón de Ulloa I Biota Colombiana. (n.d.). Retrieved April 15, 2020, from https ://revistas.humboldt.org.co/index.php/biota/article/view/266/264

Jaimes, J. H. J. (2018). Tardígrados (Animalia: Tardigrada) de la Reserva El Diviso - Santander, Colombia. Journal of Chemical Information and Modeling, 53(9), 1689-1699. https://doi. org/10.1017/CBO9781107415324.004

Konopka, C. L., Adaime, M. B., \& Mosele, P. H. (2015). Active Teaching and Learning Methodologies: Some Considerations. Creative Education, 06(14), 1536-1545. https://doi.org/10.4236/ ce.2015.614154

Leary, M., Mazur, M., McMillan, M., Brandt, M., \& Subic, A. (2015). [DesktopLabs] Desktop laboratories: Web Share and Additive Manufacture of Engineering Educational Models. Procedia Technology, 20, 111-116. https://doi.org/10.1016/j.protcy.2015.07.019

Lujan, H. L., \& Dicarlo, S. E. (2006). First-year medical students prefer multiple learning styles. American Journal of Physiology Advances in Physiology Education, 30, (pp. 13-16). https://doi. org/10.1152/advan.00045.2005

Madeira, N. G., Macharelli, C. A., Pedras, J. F., \& Delfino, M. C. N. (2002). Education in primary school as a strategy to control dengue. Revista Da Sociedade Brasileira de Medicina Tropical, 35(3), 221-226. https://doi.org/10.1590/S0037-86822002000300004

Marques, J. M. M. C. (2008). Inter and multidisciplinarity in engineering education. International Journal of Mechanics and Materials in Design, 4(2), 229-237. https://doi.org/10.1007/s1099 9-008-9056-4

Mauricio, P., Castellanos, A., Dios, A. Q., \& Ortegon, A. C. (n.d.). The lack of environmental education in the training of environmental engineers in Colombia.

Mcmenamin, P. G., Quayle, M. R., Mchenry, C. R., \& Adams, J. W. (2014). The production of anatomical teaching resources using three-dimensional (3D) printing technology. Anatomical Sciences Education, 7(6), 479-486. https://doi.org/10.1002/ase.1475

Melchels, F. P. W., Domingos, M. A. N., Klein, T. J., Malda, J., Bartolo, P. J., \& Hutmacher, D. W. (2012). August 1). Additive manufacturing of tissues and organs. Progress in Polymer Science, 37, 1079-1104. https://doi.org/10.1016/j.progpolymsci.2011.11.007

Neumüller, M., Reichinger, A., Rist, F., \& Kern, C. (2014). 3D printing for cultural heritage: Preservation. Accessibility, Research and Education. https://doi.org/10.1007/978-3-662-44630-0_9

Overview of materials for Thermoplastic Polyurethane, Elastomer, Glass Filled. (n.d.). Retrieved February 3, 2020, from https:// matweb.com/search/DataSheet.aspx?MatGUID=2fe782a31c 4b4bed984b49651762b086\&ckck=1

Parker, L., Prabawa-Sear, K., \& Kustiningsih, W. (2018). How young people in Indonesia see themselves as environmentalists: Identity, behaviour, perceptions and responsibility. Indonesia and the Malay World, 46(136), 263-282. https://doi.org/10.1080/13639 811.2018 .1496630

Peacock, K. (2012). Museum education and art therapy: Exploring an innovative partnership. Art Therapy, 29(3), 133-137. https://doi. org/10.1080/07421656.2012.701604

PLA Density - What's the Density of PLA Filament / Plastic? I All3DP. (n.d.). Retrieved February 3, 2020, from https://all3dp.com/2/pladensity-what-s-the-density-of-pla-filament-plastic/

Reich, Y. (2020). The coronavirus pandemic: How can design help? Research in Engineering Design, 31(2), 141-142. https://doi. org/10.1007/s00163-020-00337-6

Reilly, P. (2015). Additive archaeology: An alternative framework for recontextualising archaeological entities. Open Archaeology, 1(1), 225-235. https://doi.org/10.1515/opar-2015-0013
Sabates, R., Westbrook, J., Akyeampong, K., \& Hunt, F. (2010). School Drop Out: Patterns, Causes, Changes and Policies. United Nations Educational, Scientific and Cultural Organisation (UNESCO): Paris, France. . Retrieved from https://unesd oc.unesco.org/images/0019/001907/190771e.pdf

Sauerwein, M., Doubrovski, E., Balkenende, R., \& Bakker, C. (2019). Exploring the potential of additive manufacturing for product design in a circular economy. Journal of Cleaner Production, 226, 1138-1149. https://doi.org/10.1016/j.jclep ro.2019.04.108

Schelly, C., Anzalone, G., Wijnen, B., \& Pearce, J. M. (2015). Opensource 3-D printing technologies for education: Bringing additive manufacturing to the classroom. Journal of Visual Languages and Computing, 28, 226-237. https://doi.org/10.1016/j. jvlc.2015.01.004

Stern, A., Rosenthal, Y., Dresler, N., \& Ashkenazi, D. (2019). Additive manufacturing: An education strategy for engineering students. Additive Manufacturing, 27(April), 503-514. https://doi. org/10.1016/j.addma.2019.04.001

Stevens, S., Andrade, R., \& Page, M. (2016). Motivating young Native American students to pursue STEM learning through a culturally relevant science program. Journal of Science Education and Technology, 25(6), 947-960. https://doi.org/10.1007/s1095 6-016-9629-1

Suárez, M. F., \& Nelson, M. J. (1981). Registro de altitud del Aedes aegypti en Colombia. Biomédica, 1(4), 225. https://doi. org/10.7705/biomedica.v1i4.1809

Sun, L., Hua, G., Cheng, T. C. E., \& Wang, Y. (2020). How to price $3 \mathrm{D}$-printed products? Pricing strategy for $3 \mathrm{D}$ printing platforms. International Journal of Production Economics. https://doi. org/10.1016/j.ijpe.2019.107600

Thingiverse - Digital Designs for Physical Objects. (n.d.). Retrieved April 14, 2020, from https://www.thingiverse.com/

Thompson, M. K., Moroni, G., Vaneker, T., Fadel, G., Campbell, R. I., Gibson, I., \& Martina, F. (2016). Design for additive manufacturing: Trends, opportunities, considerations, and constraints. CIRP Annals - Manufacturing Technology, 65(2), 737-760. https://doi. org/10.1016/j.cirp.2016.05.004

TPU 1.75mm 3D Printer Filament. (n.d.). Retrieved February 3, 2020, from https://rigid.ink/products/tpu-1-75mm-0-03mm-tolerance

Tsay, M., \& Brady, M. (2010). A case study of cooperative learning and communication pedagogy: Does working in teams make a difference? Journal of the Scholarship of Teaching \& Learning, 10(2), 78-89. Retrieved from https://proxy-remote.galib.uga. edu/login?url=https://search.ebscohost.com/login.aspx?direc $\mathrm{t}=$ true $\& \mathrm{db}=$ ehh $\& \mathrm{AN}=52225427 \&$ site $=$ eds-live

Tsukii, Y. (2009). Chapter 5-6 Tardigrade Ecology. Museum, 2(Ramazzotti 1972).

Ullah, S. K. (2013). Lack of environmental sustainability in youth training at higher education. Journal of Education and Vocational Research, 4(9), 254-258. https://doi.org/10.22610/jevr.v4i9.128

Vanderhuck, M. G. (1995). ANALISIS PALINOLOGICO DE LA MIEL Y LA CARGA DE POLEN COLECTADA POR Apis mellifera EN EL SUROESTE DE ANTIOQUIA, COLOMBIA. (Vol. 3).

Vargha, B., \& Tuba, Z. (2002). Investigations on ecological effects of heavy metal pollution in hungary by moss-dwelling water bears (tardigrada), as bioindicators. In Ann Agric Environ Med (Vol. 9).

Velásquez Giraldo, A. M., Vélez Acosta, L. M., \& Zuluaga Gallego, R. (2013). Ingeniería y Ciencia Physicochemical and Microbiological Characterization of Apis mellifera sp. Honey from Southwest of Antioquia in Colombia. Retrieved from https://www.eafit.edu. co/ingciencia

Virgin, L. (2017). Enhancing the teaching of structural dynamics using additive manufacturing. Engineering Structures, 152, 750-757. https://doi.org/10.1016/j.engstruct.2017.09.052 
Walls, S., Corney, J., \& Annamalai Vasantha, G. V. (2014). Relative energy consumption of low-cost $3 D$ printers.

Wankat, P. C., \& Oreovicz, F. S. (2015). Teaching Engineering. Retrieved from https://books.google.com.co/books?id=UBFBgAAQBAJ

Weinstock, G. M., Robinson, G. E., Gibbs, R. A., Worley, K. C., Evans, J. D., Maleszka, R., \& Wright, R. (2006). Insights into social insects from the genome of the honeybee Apis mellifera. Nature, 443(7114), 931-949. https://doi.org/10.1038/nature05260

Wittbrodt, B. T., Glover, A. G., Laureto, J., Anzalone, G. C., Oppliger, D., Irwin, J. L., \& Pearce, J. M. (2013). Life-cycle economic analysis of distributed manufacturing with open-source 3-D printers. Mechatronics, 23(6), 713-726. https://doi.org/10.1016/j.mecha tronics.2013.06.002
Xue, Y., \& Larson, R. C. (2015). STEM crisis or STEM surplus? Yes and yes. Monthly Labor Review, 2015(5). https://doi.org/10.21916 /mlr.2015.14

Zhang, F., Markopoulos, P., \& Bekker, T. (n.d.). Children's Emotions in Design-Based Learning: A Systematic Review. https://doi. org/10.1007/s10956-020-09830-y

Publisher's Note Springer Nature remains neutral with regard to jurisdictional claims in published maps and institutional affiliations. 